УДК 371. 388.:37.036.5:004.9

Соколюк Олександра Миколаївна

кандидат педагогічних наук, завідуюча відділом лабораторних комплексів засобів навчання Інститут інформаційних технологій і засобів навчання НАПН України, м. Київ, Україна a.sokolyuk@mail.ru

\title{
ЕЛЕМЕНТИ НАВЧАЛЬНОЇ ТВОРЧОСТІ У ПРОЦЕСІ ВИКОНАННЯ ІНТЕРНЕТ ОРІЕНТОВАНИХ НАВЧАЛЬНИХ ДОСЛІДЖЕНЬ 3 ФІЗИКИ У СЕРЕДНІЙ ШКОЛІ
}

\begin{abstract}
Анотація. Недостатня розробленість проблеми розвитку навчальної творчості учнів засобами інформаційно-комунікаційних технологій як у теоретичному, так і в практичному плані обумовлює необхідність пошуку нових шляхів ефективної організації навчальновиховного процесу в інформаційно-освітньому середовищі середньої загальноосвітньої школи. У статті розглянуті проблеми організації навчальних досліджень 3 фізики у загальноосвітній середній школі як творчо орієнтованої навчальної діяльності учнів. Визначено поняття «навчальна творчість», проаналізовано алгоритми діяльності учнів у процесі виконання навчальних досліджень 3 фізики з точки зору прояву елементів творчості як одиниць інтелектуальної активності.
\end{abstract}

Ключові слова: навчальні дослідження; дослідницькі вміння; навчальна творчість; інформаційно-комунікаційні технології.

\section{1. ВСТУП}

Постановка проблеми. Згідно навчальних програм учням доводиться виконувати різноманітні дослідження, на основі яких формуються нові поняття, встановлюються нові для учнів закономірності, зокрема з курсу фізики. Отже, для учнів навчальні дослідження служать джерелом нових знань і від того, як учні опанували системою дослідницьких умінь, значною мірою залежать їхні успіхи в засвоєнні нових знань і їх застосуванні.

3 іншого боку, усе більше проникнення мережних технологій, зокрема Інтернету, у повсякденний побут школярів і широке використання інформаційно-комунікаційних технологій (IКТ) у системі середньої загальної освіти формує низку проблем їх раціонального використання в навчальному процесі. Зокрема, стає очевидним, що в процесі оволодіння знаннями в галузі природничих дисциплін, від успішного оволодіння учнем уміннями використовувати засоби IКT у навчальній експериментальній діяльності залежать його успіхи в засвоєнні нових знань і їх застосуванні в найрізноманітніших професіях, які затребувані в інформаційному суспільстві. Однак, будь-яке дослідження потребує від суб'єкта діяльності певного рівня інтелектуальної активності, яка, на думку більшості вчених, $є$ проявом творчості. Отже, актуальним стає виокремлення елементів творчості в процесі виконання Інтернет орієнтованих навчальних досліджень з фізики у середній школі.

Аналіз останніх досліджень і публікацій. Як показує аналіз наукових джерел, як найповніше розроблено питання про формування експериментальних умінь під час здійснення власне експерименту, а також умінь спостерігати явища на основі розуміння структури дослідницької діяльності. Розглядаючи генезис поняття "дослідницька діяльність", Д. В. Кошелєва [7], звертає увагу на історію проблеми, яка бере свій початок з часів Сократа, Платона й Аристотеля. Автор зазначає видатну роль 
К. Д. Ушинського і Я.-А. Коменського у доведенні необхідності дослідницького навчання. Отже, обране до розгляду питання має глибокі історичні корені.

На використання дослідницького підходу в процесі навчання фізики в середній школі звертали увагу багато дослідників другої половини XX століття.

Аналіз дисертаційних робіт показує, що сучасний етап розвитку педагогічної думки характеризується зверненням низки вчених до проблеми застосування дослідницьких методів у сучасній освіті: вивчається дослідницька поведінка, елементи дослідницького навчання тощо $[6 ; 10 ; 11 ; 15]$. Більшість авторів приходять до висновку, що дослідницькі експериментальні вміння виражаються в здатності учня здійснювати діяльність, яка відповідає вимогам науково-дослідної діяльності, відповідає логіці наукового дослідження. Зокрема, проведений О. С. Кодіковою педагогічний експеримент показує, що для формування в учнів дослідницьких умінь на належному рівні не можна обмежуватися формуванням окремих експериментальних умінь, а необхідно навчати школярів методиці дослідницької роботи [6].

Різні аспекти формування дослідницьких умінь учнів розглядають у своїх дослідженнях М. Ю. Кожухова (2004), Н. Л. Головізніна (2005), О. А. Юлпатова (2007) і багато інших сучасних дослідників.

Проблемам творчості, формуванню та прояву творчих здібностей, їх діагностиці присвячено багато досліджень у психології і педагогіці. Зокрема, цим займалися російські і вітчизняні дослідники В. Н. Ананьєв, Д. Б. Богоявленська, Л. С. Виготський, Л. С. Рубінштейн, Б. М. Теплов, Я. А. Пономарьов, А. Цибуля, В. О. Моляко, В. А. Роменець, В. Д. Шадриков та ін.

На творчу компоненту дослідницького підходу в навчальному процесі звертають увагу у своїх дослідженнях О. І. Гур'єв, О. М. Полякова, Р. І. Малафеєв, М. Ю. Піотровський, Є. А. Самойлов, О. С. Демент'єва, В. В. Дрозіна.

Здобутки інформатизації загальної середньої освіти викликали появу досліджень, спрямованих на вивчення впливу інформаційно-комунікаційних технологій (IКT) на організацію навчальних досліджень і розвитку творчості учнів. У дослідженні [5] запропоновано рівні творчої діяльності учнів в умовах використання інформаційнокомунікаційних технологій, які визначаються ступенем сформованості базових підструктур особистості й установлено, що ефективність розвитку творчої діяльності учнів засобами інформаційно-комунікаційних технологій обумовлена, з одного боку, системою організації безперервного освоєння нових програмних середовищ у навчальній діяльності, а, з іншого, - можливістю застосування отриманих навичок у самостійній творчій діяльності.

Однак, одним з висновків у згаданих дослідженнях $є$ те, що в методиці навчання фізики у середній школі питання щодо використання в практиці потенційних переваг засобів ІКТ для організації творчої навчально-пізнавальної діяльності школярів залишається невирішеним. Попри це, поряд з позитивним, у цілому, впливом ІКТ на процес шкільного навчання, спостерігаються ризики глобальної інформатизації загальної середньої освіти [4].

Отже, метою даної статті $є$ аналіз організації навчальних досліджень 3 фізики у загальноосвітній середній школі як творчо орієнтованої навчальної діяльності учнів і алгоритмів діяльності учнів у процесі виконання навчальних досліджень 3 фізики 3 точки зору прояву елементів творчості як одиниць інтелектуальної активності.

\section{2. МЕТОДИ ДОСЛІДЖЕННЯ}

У нашому дослідженні ми акцентуємо увагу на виявленні тих етапів навчального дослідження з фізики у середній загальноосвітній школі, для яких найхарактернішими $є$ 
прояви творчості учня. Другою проблемою дослідження виступає можливість вимірювання рівня прояву творчого підходу учня до організації i здійснення навчального дослідження з фізики у загальноосвітній школі.

\section{3. РЕЗУЛЬТАТИ ДОСЛІДЖЕННЯ}

Використання засобів ІКТ у процесі навчального дослідження є, на нашу думку, однією з організаційних форм навчання, у яких має прояв навчальна творчість. Суб' єкт навчальної творчості у процесі здійснення навчального дослідження «перекладає» певні етапи діяльності на апаратно-програмні засоби (АПЗ), які позбавляють його від виконання «рутинних» дій. Наприклад, АПЗ здатні робити необхідні обчислення (навіть такі, якими учень ще не опанував), здійснювати сортування результатів вимірювань (за різними параметрами), будувати графіки, діаграми тощо. У випадку використання мережних технологій в учня з'являється можливість контекстного звертання до необхідної йому інформації відносно процесів (явищ), які він досліджує. Отже, навчальне дослідження, яке традиційно було «замкнутим» у межах робочого місця учня, набуває властивостей «відкритого» середовища дослідження, спираючись на інформаційні ресурси комп'ютерної мережі, зокрема мережі Інтернет. Такий підхід до організації навчальних досліджень спонукає до зміни процесуально-змістовних i організаційних основ шкільної освіти під час вивчення природничо-математичних дисциплін.

Виключення рутинної складової навчальної діяльності вивільняє час, необхідний для творчої діяльності суб' єкта, у нього з'являється можливість реалізації варіативних підходів до розв'язання навчального завдання, відходу від «жорсткого» алгоритму діяльності, який задається інструкцією до навчального дослідження. Однак, активізація пізнавальної діяльності через залучення засобів ІКТ і мережних технологій можлива тільки за рахунок творчої рефлексії суб'єкта дослідження і правильно організованої навчальної діяльності.

Розглянемо декілька структур навчальної дослідницької діяльності, які можливо реалізувати з використанням засобів ІКТ і мережних технологій. На рис. 1 показано алгоритми діяльності учня в процесі здійснення навчальних досліджень різного типу.

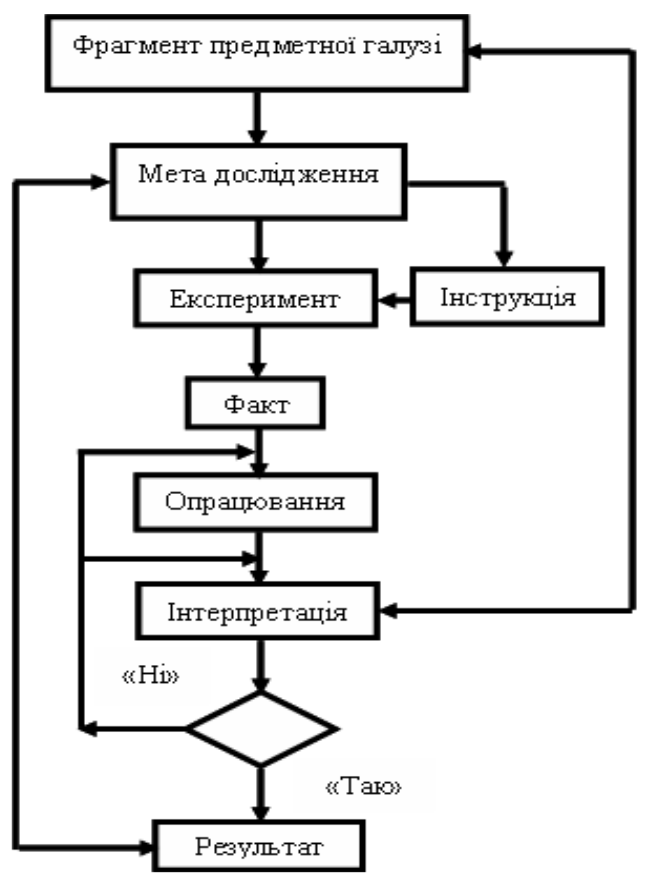


Рис. 1. Алгоритм діяльності учня в прочесі виконання навчального дослідження 3 фізики

У даному випадку елементи навчальної творчості мають прояв на рівні етапів «Опрацювання» й «Інтерпретація» фактів, отриманих у ході виконання експерименту. Інтерпретація, в основному, грунтується на порівнянні результатів опрацювання експериментальних даних 3 тим результатом, який передбачено теорією. Можна стверджувати, що саме невідповідність «образу бажаного майбутнього» з образом того, що отримано, спонукають суб'єкта діяльності висунути гіпотезу, яка може пояснювати таку невідповідність. Отже, навчальна творчість реалізується в формі гіпотези, на підставі якої суб’ єкт приймає рішення щодо подальшої діяльності.

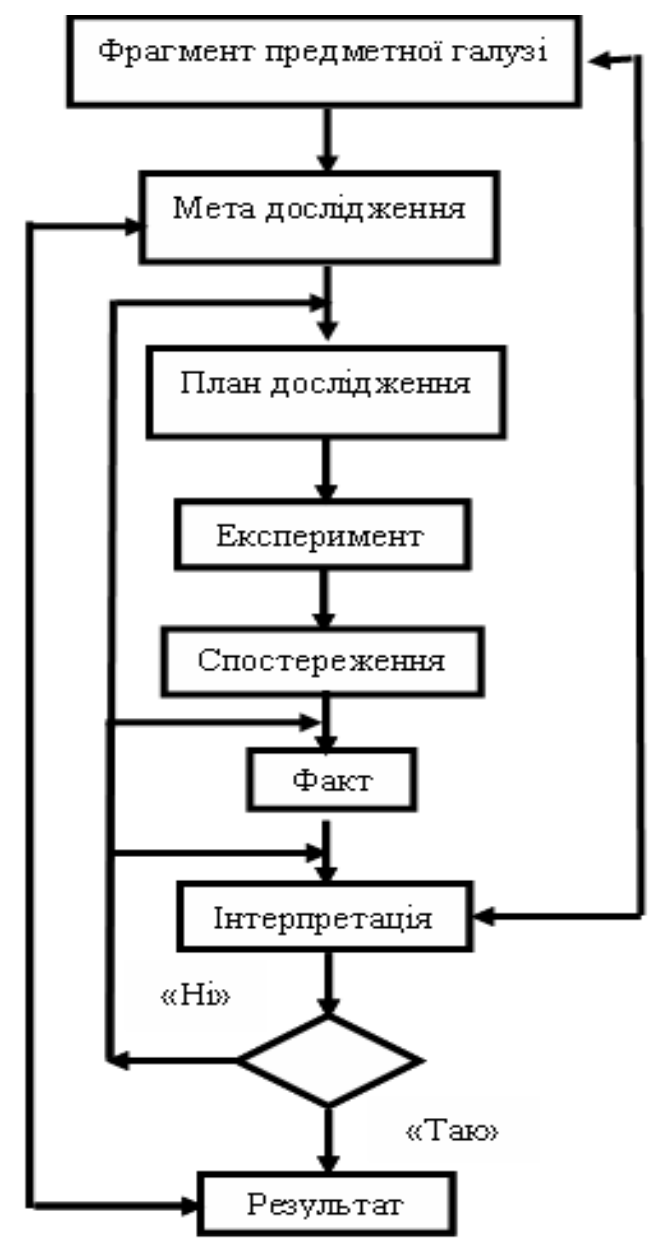

Рис. 2. Алгоритм діяльності учня в процесі виконання навчального дослідження як спостереження, яке організовано в лабораторних умовах

У даному випадку (рис. 2) елементи навчальної творчості мають прояв на рівнях планування дослідження («План дослідження»), відбору фактів спостереження («Факт») й інтерпретації («Інтерпретація») фактів, отриманих у результаті спостереження. Аналогічно до випадку, який описано вище, інтерпретація, у більшості, грунтується на порівнянні результатів спостереження 3 тим результатом, який передбачено теорією, а вибір етапу, на який треба повернутися для досягнення запланованого результату навчального дослідження, грунтується на гіпотезі. Відмінність в тому, що, по-перше, спостерігається розширення «поля» творчості суб'єкта - можливих переходів не два, а три. По-друге, найбільш творче навантаження 
припадає на етап «План дослідження», у випадку, коли учень створює план самостійно. По-третє, на етапі «Спостереження» учень має відібрати з усієї множини фактів, що спостерігаються, саме ті факти, які відповідають меті дослідження. Процес відбору фактів є низкою гіпотез, які грунтуються як на знаннях суб'єкта того фрагменту предметної галузі, який відноситься до даного дослідження, так і передбачення суб'єктом кінцевого результату дослідження (гіпотетичне порівняння сукупності фактів з образом «бажаного майбутнього»).

Відбір з множини гіпотез такої, що найбільш продуктивна у даному випадку (дозволяє досягнути бажаного результату за меншу кількість «циклів»), може виступати як показник рівня розвитку навчальної творчості суб'єкта діяльності. Природно, що у даному випадку гіпотеза дозволяє суб'єкту сформувати локальну мету діяльності. Встановлено [16], що здатність утворювати продуктивні цілі складається як мінімум із двох взаємозалежних процесів: процесу становлення у дитини здатності створювати і виділяти продуктивні результати і процесу перетворення результатів у мету — «результат — мета — результат».

3 іншого боку, сама здатність особистості побачити протиріччя та на підставі цього сформулювати гіпотезу відносно причини виникнення протиріччя, сформувати низку дій щодо виходу із ситуації, яка склалася, $є$ важливою характеристикою інтелекту. На сучасному етапі психологічної думки творчість розглядається в парадигмі наукового опису через наслідки (творчість як екстеріоризація суб'єкта) [3, 77]. Відносно процесу навчання Б. Г. Ананьєв наголошує: «На певних рівнях інтелектуального та практичного розвитку екстеріоризація сама починає впливати на процеси засвоєння, виступаючи в якості фільтра знань і дій, які засвоюються як такі, що необхідні для творчості. Освіта суб' єкта діяльності не завершується до тих пір, поки ця діяльність здійснюється ...» [1,267].

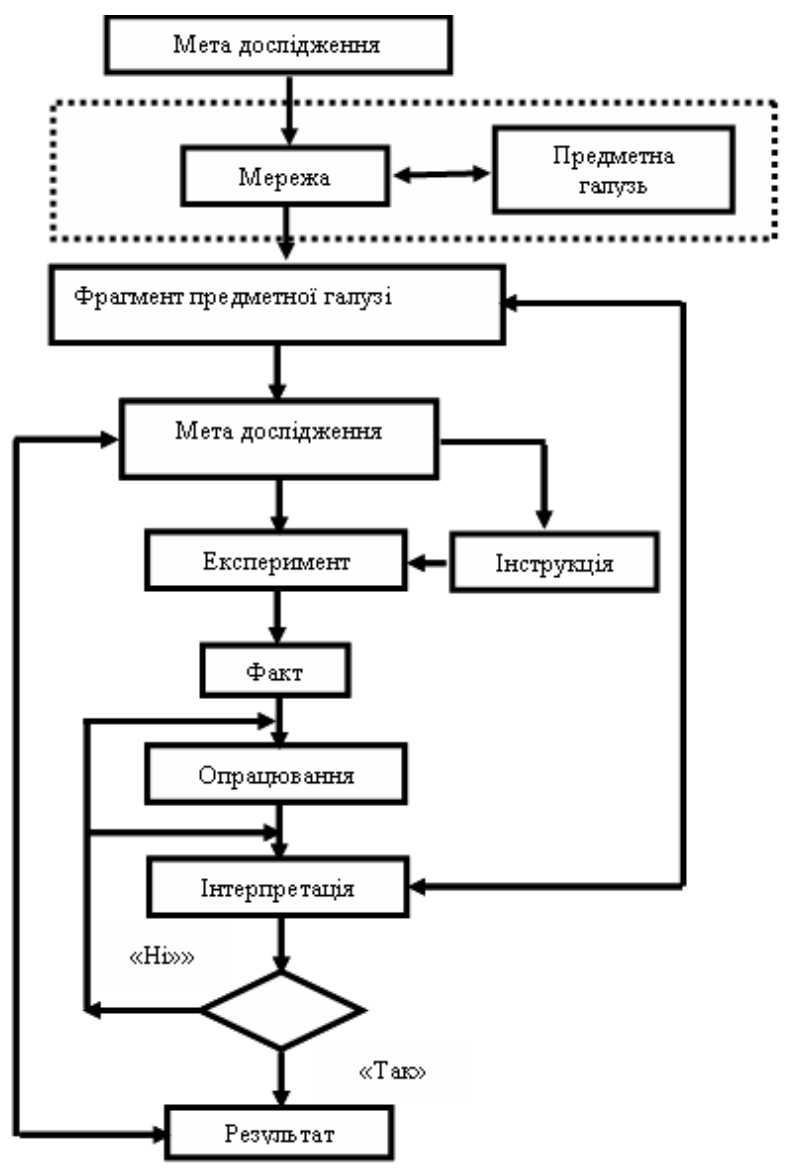


Рис. 3. Алгоритм діяльності учня в прочесі виконання навчального дослідження з фізики за умови пошуку інформаиії в комп'ютерних мережах

Діяльність суб'єкта в комп'ютерних мережах з метою пошуку інформаційного ресурсу відображена на рис. 3 як «надбудова» до основного алгоритму діяльності, який відповідає загальній структурі здійснення навчального дослідження (рис. 1). Пунктирною лінією на рис. 3 показано сферу діяльності учня в комп’ютерних мережах. На наш погляд, у даному випадку з'являється елемент інформаційно-пошукової діяльності, який з деяким наближенням можна віднести до творчої діяльності відносно предметної галузі. Як показує аналіз багатьох Інтернет-орієнтованих лабораторних робіт 3 фізики середньої школи, тобто таких робіт, навчальне дослідження у яких здійснюється у режимі on-line, саме навчальне дослідження розгортається за традиційною схемою. Але наразі виникає ілюзія відносно появи додаткового елемента навчальної творчості у предметній галузі, що вивчається.

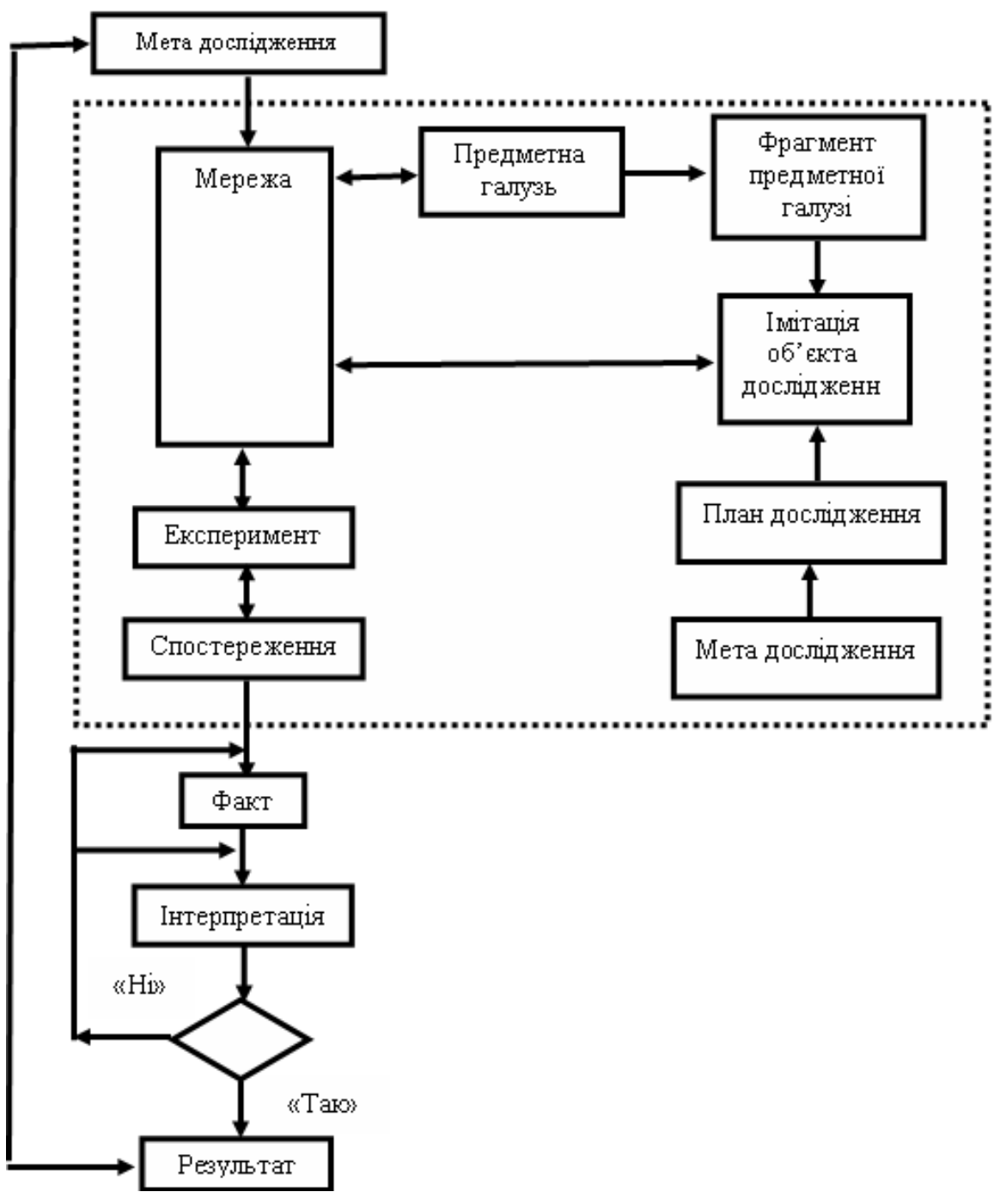

Рис. 4. Алгоритм діяльності учня в процесі виконання навчального дослідження з фізики у режимі оn-line

На рис. 4 подано один з можливих варіантів алгоритму діяльності учня у випадку навчального дослідження комп'ютерної імітації об'єкта дослідження у режимі on-line. 
Пунктирною лінією на рис. 4 показано область діяльності учня у комп'ютерних мережах. У більшості випадків мета дослідження і план дослідження (інструкція виконання дослідження з вказівками щодо керування АПЗ) $є$ невід'ємною частиною програмного засобу. Як бачимо, основні етапи навчальної діяльності, на яких мають прояв елементи навчальної творчості (знову ж таки у предметній галузі, що вивчається), знаходяться поза межами мережних технологій. Можна створити деяку множину алгоритмів, які графічно ілюструють діяльність учня у процесі виконання навчального дослідження із залученням мережних технологій, але у всіх випадках можна побачити, що елементи навчальної творчості, які безпосередньо стосуються тієї предметної галузі, що вивчається (у нашому випадку - шкільної фізики), знаходяться поза межами мережних технологій.

Ми розглядаємо навчальну творчість як творчість суб'єкта навчання в процесі навчальної діяльності, тобто діяльності, результатом (продуктом) якої є перетворення самого суб'єкта діяльності. Говорячи про елементи навчальної творчості, ми спираємося на дослідження Д. Б. Богоявленської, яка виокремлює i розглядає інтелектуальну активність як одиницю творчості [2].

Д. Б. Богоявленська приходить до висновку, що інтелектуальна активність - це інтегральне утворення, яке має прояв в обізнаній діяльності, що виходить за межі вимог даної проблемної ситуації. Отже, суб'єкт навчання, проявляючи інтелектуальну активність у процесі власної навчальної діяльності 3 метою подолання проблемної ситуації (перетворення суб' єктивної проблемної ситуації у «безпроблемну»), врештірешт «перетворює» себе. Отже, навчальну творчість ми розуміємо як процес створення суб'єктивних цінностей (розвиток дитини в онтогенезі). Аналізуючи алгоритми діяльності учнів у процесі навчального дослідження з точки зору наявності (прояву) елементів навчальної творчості, ми також виходимо з позиції Д. Б. Богоявленської, яка досліджує творчість не за продуктом, а за процесом.

3 іншого боку, у навчальному процесі загальноосвітньої школи рівні навчальної творчості визначаються, у першу чергу, рівнем продуктивності інтелектуальної діяльності учня у проблемній ситуації: правильність розв'язання навчальної задачі, відповідь на тестові завдання тощо. Окрему позицію на сьогоднішній день займають навчальні проекти, у яких, як відзначається багатьма дослідниками, відкривається багато можливостей для прояву навчальної творчості. Як показало дослідження Г. О. Лагутіної, виконання навчальних проектів, спрямованих на розробку методик експерименту для навчального дослідницького процесу, $\epsilon$ ефективним засобом формування цілісної системи умінь здійснювати експериментальну діяльність [8]. До аналогічних висновків приходить О. В. Плащева [12].

Нами була розроблена й експериментально апробована методика оцінювання продукту навчальної творчості — навчального проекту з фізики [13; 14].

Розроблена методика використання проектних технологій навчання фізики у старших класах 3 НЗ базується на використанні інформаційних предметно орієнтованих навчальних проектів, виконання яких передбачає активне використання засобів IКТ для пошуку необхідної інформації в просторі Інтернету. Предметна орієнтованість навчального проекту визначається відповідністю проектних завдань до навчальної програми курсу фізики.

Творчий характер проекту визначається, у першу чергу, тим, що вимагає максимально вільного підходу до відбору і структурування інформації, яка знайдена учнем в Інтернет-просторі, оформленні результатів проекту i його презентації 3 використанням мультимедійних технологій.

Сутність оцінювання полягає в тому, що навчальний проект учня, який виконаний ним самостійно, як за завданням учителя, так і на тему, яка обрана учнем самостійно у 
межах навчального предмета, який вивчається (теми, розділу, окремого фізичного явища або процесу, технічного застосування фізичної закономірності тощо) оцінюється групою учнів-екпертів безпосередньо у процесі доповіді учня за визначеною методикою. Такий підхід до вивчення продукту навчальної творчості дозволяє реалізувати праксиметричний метод у реальному навчальному процесі.

\section{4. ВИСНОВКИ ТА ПЕРСПЕКТИВИ ПОДАЛЬШИХ ДОСЛІДЖЕНЬ}

Особливостями організації навчальних досліджень 3 фізики у загальноосвітній середній школі з використанням проектної технології навчання $\epsilon$ те, що інформаційний предметно орієнтований навчальний проект $є$ спільною навчально-пізнавальною творчою діяльністю учнів, яка організована на основі Інтернет-ресурсів.

Оцінювання результатів навчальної творчості $\epsilon$ окремою проблемою, яка 3 урахуванням широкого використання IКТ у навчальному процесі, набуває ознак міждисциплінарної через те, що, як це показано вище, необхідно враховувати творчість учня як у предметній галузі, що вивчається, так і в галузі IКТ (зокрема, інформаційнопошукової діяльності, продуктивної поведінки у комп'ютерно орієнтованому середовищі тощо). Наразі аналіз результатів діяльності учня має бути чітко диференційований за певними ознаками, які дозволяють оцінювати рівень навчальної творчості у різних галузях навчальної діяльності.

\section{СПИСОК ВИКОРИСТАНИХ ДЖЕРЕЛ}

1. Ананьев Б. Г. Человек как предмет познания / Б. Г. Ананьев. - Л., 1969. - 339 с.

2. Богоявленская Д. Б. Интеллектуальная активность как проблема творчества / Д. Б. Богоявленская. — Ростов-на-Дону : Изд-во Ростовского ун-та, 1983. — 172 с.

3. Вишнякова Н. Ф. Креативная психопедагогика : монография / Н. Ф. Вишнякова. — Минск, 1995. - $240 \mathrm{c}$.

4. Жук Ю. О. Информатизация образования: надежды и риски / Ю. О. Жук // Науковий часопис НПУ імені М. П. Драгоманова. Серія № 2. Комп’ютерно-орієнтовані системи навчання: $з б$. наук. праць / Редрада НПУ імені М. П. Драгоманова, 2012. — № 13 (20). — С. 184-187.

5. Канянина Т. И. Организация творческой деятельности учащихся лицея средствами информационно-коммуникационных технологий : дис. ... канд. пед. наук : 13.00.02 / Канянина Татьяна Ивановна. - Нижний Новгород, 2005. - 223 с.

6. Кодикова Е. С. Формирование исследовательских экспериментальных умений у учащихся основной школы при обучении физике : автореф. дис. канд. пед. наук / Е. С. Кодикова. Моск. пед. гос. ун-т. М., 2000. — 21 с.

7. Кошелева Д. В. Генезис понятия «исследовательские умения» / Д. В. Кошелева // Знание. Понимание. Умение. - 2011. - № 2. - С. 218-221.

8. Лагутина А. А. Формирование исследовательских умений методического обеспечения эксперимента в физическом образовании : дис. ... канд. пед. наук : 13.00.02 / Лагутина Анна Александровна. - СПб., 2006. - 162 с.

9. Малафеев Р. И. Развитие творческих способностей учащихся при изучении физики в 8-летней школе : автореф. ... канд. пед. наук : 13.00 .02 / Р. И. Малафеев. — М., 1967. — 22 с.

10. Мураховский И. Е. Методические проблемы организации исследовательской деятельности учащихся на занятиях по физике : автореф. дис. канд. пед. наук : 13.00 .02 / И. Е. Мураховский. - СПб., 1996. - 20 с.

11. Мустафаев С. Т. Реализация исследовательского подхода при обучении физике : автореф. дисс. канд. пед. наук : 13.00.02 / С. Т. Мустафаев. - М., 1989. - 18 с.

12. Плащевая Е. В. Методика формирования исследовательских умений в проектной деятельности у учащихся основной школы при изучении физики : дисс. ... канд. пед. наук : 13.00.02 / Плащевая Елена Викторовна. — М., 2009. — 187 с.

13. Соколюк О. М. Методика формування контрольно-оцінювальних умінь учнів середньої школи при вивченні предметів природничо-математичного циклу / Ю. О. Жук, О. М. Соколюк // Науковий часопис Національного педагогічного університету 
ім. М. П. Драгоманова. Серія № 5. Педагогічні науки: реалії та перспективи. - Вип. 12. - К. : Вид-во НПУ ім. М. П. Драгоманова, 2008. - 356 с.

14. Соколюк О. М. Особливості використання засобів ІКТ у предметно орієнтованій проектній діяльності / О. М. Соколюк // Інформаційні технології і засоби навчання [Електронний pecypc]. — 2011. — № 6(26). — Режим доступу до журн. : http://www.journal.iitta.gov.ua.

15. Шабашов Л. Д. Развитие исследовательских умений учащихся средней школы : дисс. ... канд. пед. наук : 13.00.02 / Л. Д. Шабашов. - С.-Пб, 1997. — 136 с.

16. Швалб Ю. М. Психологические модели целеполагания / Ю. М. Швалб. - К. : Стидос, 1997. $-238 \mathrm{c}$.

Матеріал надійшов до редакиії 26.04.2013 p.

\title{
ЭЛЕМЕНТЫ УЧЕБНОГО ТВОРЧЕСТВА В ПРОЦЕССЕ ВЫПОЛНЕНИЯ ИНТЕРНЕТ ОРИЕНТИРОВАННЫХ УЧЕБНЫХ ИССЛЕДОВАНИЙ ПО ФИЗИКЕ В СРЕДНЕЙ ШКОЛЕ
}

\author{
Соколюк Александра Николаевна \\ кандидат педагогических наук, заведующая отделом лабораторных комплексов средств обучения \\ Институт информационных технологий и средств обучения НАПН Украины, г. Киев, Украина \\ a.sokolyuk@ mail.ru
}

\begin{abstract}
Аннотация. Недостаточная разработанность проблемы развития учебного творчества учащихся средствами информационно-коммуникационных технологий как в теоретическом, так и в практическом плане обуславливает необходимость поиска новых путей эффективной организации учебно-воспитательного процесса в информационнообразовательной среде средней общеобразовательной школы. В статье рассмотрены проблемы организации учебных исследований по физике в общеобразовательной школе как творчески ориентированной учебной деятельности учащихся. Дано определение понятия «учебное творчество», проанализированы алгоритмы деятельности учащихся в процесс се выполнения учебных исследований по физике с точки зрения проявления элементов творчества как единиц интеллектуальной активности.
\end{abstract}

Ключевые слова: учебные исследования; исследовательские умения; учебное творчество; информационно-коммуникационные технологии.

\section{ELEMENTS OF EDUCATIONAL CREATIVITY IN THE PROCESS OF INTERNET-BASED EDUCATIONAL RESEARCH ON PHYSICS IN SECONDARY SCHOOL}

\author{
Olexandra M. Sokolyuk \\ $\mathrm{PhD}$ (pedagogical sciences), head of the Department of laboratory comlexes and learning tools \\ Institute of Information Technology and Learning Tools of the NAPS of Ukraine, Kyiv, Ukraine \\ a.sokolyuk@mail.ru
}

\begin{abstract}
Absract. Problem of pupil's educational creativity development by means of information and communication technology both theoretical and practical insufficient elaboration stipulates the necessity to find out new ways (approaches) of educational process effective arrangement within secondary school information-educational environment. Problems of educational investigations on physics in secondary school as pupil's creative-oriented educational activities are considered in the present article. Conception of "educational creativity" is defined, algorithms of pupil's activities in the process of educational investigations on physics execution are analyzed from the creativity elements manifestation as intellectual activity unit point of view.
\end{abstract}

Keywords: educational research; investigation skills; educational creativity; information and communication technologies. 


\section{REFERENCES (TRANSLATED AND TRANSLITERATED)}

1. Anan'ev B. G. Man as an object of knowledge / B.G. Anan'ev. — L., 1969. — 339 s. (in Russian)

2. Bogojavlenskaja D. B. Intellectual activity as a problem of creativity / D. B. Bogojavlenskaja. Rostov-na-Donu: Izd-vo Rostovskogo un-ta, 1983. - 172 s. (in Russian)

3. 3.Vishnjakova N. F. Creative psychopedagogy: / N. F. Vishnjakova. — Minsk, 1995. — 240 s. (in Russian)

4. Zhuk Ju. O. Education informatization: prospects and risks / Ju. O. Zhuk // Naukovij chasopis NPU imeni M.P. Dragomanova. Serija \# 2. Komp'juterno-orientovani sistemi navchannja: Zb. nauk. prac' / Redrada NPU imeni M. P. Dragomanova, 2012. — \# 13 (20). — S. 184-187. (in Ukrainian)

5. Kanjanina T. I. Organization of creative activity of students of the Lyceum means of information and communication technologies : dis. ... kandidata ped. nauk : 13.00.02 / Kanjanina Tat'jana Ivanovna. — Nizhnij Novgorod, 2005. — 223 s. (in Russian)

6. Kodikova E. S. Formation of experimental research skills in primary school students in teaching physics : avtoref. dis. kand. ped. nauk / E. S. Kodikova. - Mosk. ped. gos. un-t. M., 2000. — 21 s. (in Russian)

7. Kosheleva D. V. The genesis of the concept of "research skills"/ D. V. Kosheleva // Znanie. Ponimanie. Umenie. - 2011. — \# 2. - S. 218-221. (in Russian)

8. Lagutina A. A. Formation of the research skills of methodological support of the experiment in physical education : dis. ... kand. ped. nauk : 13.00.02 / Lagutina Anna Aleksandrovna. — SPb., 2006. - 162 s. (in Russian)

9. Malafeev R. I. The development of creative abilities of students in the study of physics in 8-year-old school: avtoref. ... kand. ped. nauk : 13.00.02 / R. I. Malafeev. — M., 1967. — 22 s. (in Russian)

10. Murahovskij I. E. Methodological problems of the organization of research activities of students in the classroom for physics: avtoref. ... kand. ped. nauk : 13.00.02 / I. E. Murahovskij. — SPb., 1996. -20 s. (in Russian)

11. Mustafaev S. T. The implementation of the research approach in teaching physics: avtoref. ... kand. ped. nauk : 13.00.02 / S. T. Mustafaev. — M., 1989. — 18 s. (in Russian)

12. Plashhevaja E. V. Methods of forming research skills in project activities at the primary school students in the study of physics : diss. ... kand. ped. Naukv : 13.00 .02 / Plashhevaja Elena Viktorovna. - M., 2009. - 187 s. (in Russian)

13. Sokolyuk O. M. Methods of forming control and appraisal skills of high school students in the study of natural science subjects and mathematics cycle / Yu. O. Zhuk, O. M. Sokolyuk // Naukovyi chasopys Natsionalnoho pedahohichnoho universytetu im. M. P. Drahomanova. Seriia № 5. Pedahohichni nauky: realii ta perspektyvy. - Vyp. 12. - K. : Vyd-vo NPU im. M. P. Drahomanova, 2008. - 365 s. (in Ukrainian)

14. Sokolyuk O. M. Features of ICT use in the subject-oriented project activity / O. M. Sokolyuk // Informatsiini tekhnolohii i zasoby navchannia [online]. — 2011. — № 6(26). — Available from : http://www.journal.iitta.gov.ua. (in Ukrainian)

15. Shabashov L. D. The development of research skills of high school students : diss. ... kand. ped. nauk : 13.00.02 / L. D. Shabashov. — S.-Pb, 1997. — 136 s. (in Russian)

16. Shvalb Ju. M. Psychological models of goal-setting / Ju. M. Shvalb. — K. : Stidos, 1997. — 238 s. (in Ukrainian) 